\title{
(The Markan and Matthean) Jesus' appropriation and criticism of the Torah: The question of divorce
}

\begin{abstract}
Author:
Eben Scheffler ${ }^{1}$

Affiliation:

${ }^{1}$ Department of Old

Testament and Ancient

Near Eastern Studies,

University of South Africa

Correspondence to:

Eben Scheffler

email:

schefeh@unisa.ac.za

Postal address:

Department of Old

Testament and Ancient

Near Eastern Studies,

PO Box 392, Unisa, Pretoria

0003, South Africa

Dates:

Received: 30 Nov. 2010

Accepted: 14 Jan. 2011

Published: 07 June 2011

How to cite this article: Scheffler, E., 2011, 'The (Markan and Matthean) Jesus' appropriation and criticism of the Torah:

The question of divorce', HTS Teologiese Studies/ Theological Studies 67(1), Art. \#1006, 6 pages. DOI: 10.4102/hts.v67i1.1006
\end{abstract}

(C) 2011. The Authors. Licensee: OpenJournals Publishing. This work is licensed under the Creative Commons Attribution License.
According to the Gospel of Matthew, Jesus functions as a Moses figure who, in the Sermon on the Mount, gave the new law of the kingdom of God. In this article it is argued that Jesus drew his ethic from his Jewish tradition, as manifested particularly in the Pentateuch. However, although being an inspiring source, to Jesus the Pentateuch (or scripture) was not an authority that could not be challenged or criticised. This is illustrated by focusing on the question of divorce (Mk 10:2-12; Mt 5:27-32; 19:3-12). It is argued that Jesus' use of the Pentateuch was guided by an ethic of compassion. In view of Jesus' stance, an uncritical use of the Bible (as manifested for example in many Christian circles) ironically contradicts the Bible's own message and nature.

\section{Introduction}

\section{On Dawkins, Jesus and Bible reading}

In his book, The God Delusion, the British biologist Richard Dawkins argues his case for atheism not only on biological grounds, but also on the basis of what he (as an ordinary but attentive Bible reader) observes regarding the specific contents of the Old and New Testaments. What affronts Dawkins especially about the latter is the condoning of war and violence in both the Old and New Testaments. Surprisingly, Dawkins commented positively on the historical Jesus, saying that he proudly wears his T-shirt (received as a gift), imprinted with the words 'Atheists for Jesus' (Dawkins 2005, 2006:250). ${ }^{1}$

In his book, Dawkins makes some observations on how Jesus interpreted the Bible and then concludes that Jesus sets the example on how it should be read and interpreted. According to him (Dawkins 2006:250), Jesus 'was not content to derive his ethics from the scriptures of his upbringing. He explicitly departed from them, for example when he deflated the dire warnings about breaking the Sabbath.' My question in this article is whether Dawkins's assessment of Jesus' Bible interpretation is tenable, especially with regard to the Pentateuch? Can (and should) 'believing' Bible readers benefit from the 'atheist' Dawkins' insight into the historical Jesus? ${ }^{2}$

Dawkins does not display a historical-critical insight into the synoptic Gospels or the historical Jesus. His criticism is actually a 'naïve-critical' reaction to a literal, fundamentalist or face-value reading of the Bible, the latter most probably being part of the tradition he was raised in. I therefore do not pursue his thoughts any further. In what follows I limited myself to an instance in the synoptic Gospels where Jesus challenges Old Testament thought and specifically, the perspective from the Torah or Pentateuch that functioned as the 'Jewish canon' ${ }^{\prime 3}$ in Jesus' day.

As far as Matthew's gospel is concerned, the antitheses of the Sermon of the Mount (Mt 5:21-48) obviously come to mind. In order to obtain a better relief of Matthew 5:27-32 concerning divorce, the pre-Matthaean (Markan) tradition will first scrutinised. Conjectures will also be made about Jesus' own views, for which we have, as far as divorce is concerned, an interesting source from Paul's first letter to the Corinthians (ch. 7). But since Jesus' words and views are not directly accessible, some remarks on the possibility of historical Jesus studies are called for.

1.In his autobiography, the Afrikaans author André Brink, also criticises especially the Old Testament for its violence, but remarks (contrary to Dawkins) regarding Jesus things are not much better ('Selfs Jesus is verdag...'; 2009:20.) His reference to Mark 3:31-35, Matthew 12:46-50 and Luke 8:19-21 in this regard is of course indicative of his ignorance of a contextual critical reading of the text. For an overview of the diverse views on war and violence in the Hebrew Bible, see my War and violence in the Old Testament world: Various views (Scheffler 2009a:1-17) as well as Niditch (1993) and Van Dyk (2003). Of non-believers having a positive interest in (the historical) Jesus, see Machoveč (1972) and Spong (2007).

2. I do not imply that Dawkins made any formal study of the historical Jesus. His remarks nevertheless portray an apt awareness of the historical Jesus (whose views could be in contrast, not only of the Old Testament, but even the New Tetament).

3.Quotation marks are used here because, although the Torah was the most authoritative corpus of books for the Jews, (touching them defiled the hands) the Pentateuch at that sthe Christianity, or the Tanak in Judaism. Concepts of 'Word of God' and 'canon' should therefore not, from a present-day perspective, be projected into Jewish views of the 1st century Testament (see Davies 1998:37-58). 


\section{On the (im)possibility of studying the historical Jesus}

In order that the questions posed are not too easily sidestepped or ignored by scholars who regard historical Jesus studies to be an impossibility or in a dead end (e.g. Vorster 2008:46), some remarks need to be made on the (im)possibility of historical Jesus research.

Given that we have no documents written by Jesus of Nazareth or archaeological artefacts that can be directly linked to his earthly existence, ${ }^{4}$ many scholars question the possibility of (re)constructing the life of the historical Jesus and his teaching. ${ }^{5}$ The exegete always stands before the text and is therefore not able to grasp the history behind the text, which is forever lost. This objection by contemporary scholars actually attempts to teach us what we know since the time of Albert Schweitzer (1906) or even before: No reconstruction of history is possible that overlaps with what actually happened. ${ }^{6}$

However, this limitation does not only apply for the study of the historical Jesus, but for all historiography. If the quest for the historical Jesus should be abandoned, then all historical quests should be abolished, because even the news that we hear today about the events of yesterday is not a recreation of the past. Seeing that it is indeed part of human nature to reflect on the past and memorising occurs involuntarily, the historical quest is unlikely to be abandoned.

This being said, the historiographical endeavour is, by default, an imaginative attempt at construction, the product of cultural memory, which is in principle open for scholarly debate. Schnelle's (2007:53) distinction between reconstruction and construction is indeed helpful in this regard. Reconstruction, according to him, refers to the impossibility to recreate past events as it actually happened, without human interpretation. Construction refers to the legitimate endeavour to write history, in which human interpretation plays an inevitable part. If the contemporary scepticism in some circles regarding historical Jesus research reminds us of the relativity and preliminary nature of our constructions and not to be tempted to regard the latter as reconstructions, these warnings are to the point. However, if the scepticism is intended as a foregone conclusion that all attempts at constructing Jesus' life and teaching should be abandoned, it is out of order, because of the implication that all historiography should then be abandoned, since no history that overlaps with what actually occurred in the past. It implies that one should walk today through the streets of what used to be ancient Rome as if blindfolded.

Without underestimating the search for Jesus' words and deeds in terms of particular sayings and specific deeds

4.Even Crossan and Reed's book Excavating Jesus: Beneath the stories, behind the texts (2001), does not deal with such artefacts, but rather with archaeological

5.For a discussion of some of these scholars' (e.g. Bultmann 1968:1-2; Schröter 2006) views, see Scheffler (2009b:240, notes 15-22.)

6.To use Von Ranke's words, 'wie es eigentlich gewesen ist'. (ipsissima verba et acta, cf. e.g. Crossan 1991:xiii-xxvi, 1994), I am of the opinion that progress can be made in Jesus research if the early Jesus tradition is scrutinised in terms of specific themes (e.g. divorce, violence, poverty, healing etc). By assessing various versions of the earliest tradition around a specific theme, different and even contrasting views can be appreciated and evaluated, after which an informed (although not infallible) construction can be made regarding the historical Jesus' own views. ${ }^{7}$

In what follows, the question of divorce ${ }^{8}$ as an example of Jesus' engagement with the Pentateuch (Torah) will be investigated. The focus is primarily on his use and interpretation of scripture and not primarily on his deeds and teaching, although the interconnectedness between both will manifest itself. I intend to indicate that at least three factors are relevant when Jesus interprets the Torah or his tradition:

- his appropriation of the tradition

- his critical engagement with the tradition when he deemed it necessary

- the criterion which he employs when he criticises the tradition.

To conclude, some (hermeneutical) remarks on Jesus as a critical Jew and the relevance of the latter notion for today will be made.

\section{Criticising and appropriating the Pentateuch: Jesus on divorce}

The Matthaean Jesus spoke about adultery and divorce thrice; twice in the Sermon on the Mount (5:27-32) and again in his rendering of Mark 10:2-12 in Matthew 19:312. In order to appreciate the relief that becomes possible through the different transmissions, it seems functional to start with Matthew's and Luke's redaction of Mark and then to return to the Sermon on the Mount. Atttention will be paid to Jesus criticism and appropriation of the Torah, and his compassionate judgment in doing so. The distinction between monogamy and polygamy in Jesus' context will manifest itself as relevant in this regard. Paul's transmission of Jesus' ('the Lord's') saying on divorce in 1 Corinthians 7 will also be considered.

\section{Translation of Mark 10:2-12}

Matthew's and Luke's use of Markcan onlybefully appreciated if a clear understanding of Mark's views, uncontaminated by a Matthaean reading of Mark or a Christian reading of Mark that is informed by Matthew's stance, are kept in mind. In order to facilitate the discussion, Mark's version is given in the translation of the New International Version (hereafter NIV), with the relevant words reflecting Jesus' appropriation of the Torah in bold, what he criticises in italics and the criterion reflecting his judgment underlined:

7.For a brief and clear summary of the complexity of the growth of the Jesus tradition, see Bornkamm ([1956] 1975:191-195).

8.It is intended to discuss Jesus teaching on love for the enemy in terms of his appropriation and criticism of the Torah in a future contribution. 
2. Some Pharisees came and tested him by asking, 'Is it lawful for a man to divorce his wife?'

3. 'What did Moses command you?' he replied.

4. They said, 'Moses permitted a man to write a certificate of divorce and send her away.'

5. 'It was because your hearts were hard that Moses wrote you this law,' esus replied.

6. 'But at the beginning of creation God 'made them male and female.'

7. 'For this reason a man will leave his father and mother and be united to his wife,

8. and the two will become one flesh.' So they are no longer two, but one.

9. Therefore what God has joined together, let man not separate.'

10. When they were in the house again, the disciples asked Jesus about this.

11. He answered, 'Anyone who divorces his wife and marries another woman commits adultery against her.

12. And if she divorces her husband and marries another man, she commits adultery.'

\section{The Markan Jesus' criticism of Deuteronomy 24:1-4 regarding divorce}

In Mark's version (v. 2) the clear intention of the Pharisees to tempt Jesus underlines their awareness that Jesus was radically against divorce. We know from 1 Corinthians 7:10 that even Paul (who himself allowed exceptions for divorce, cf. 7:15) was aware that the historical Jesus was categorically against divorce (therefore his remark 'not I, but the Lord'). The formulation of question and counter question in Mark 10:2-12 is done in such a way that a dialogue about the validity of Jewish law (and therefore scripture) is on the table. After Jesus' question the Pharisees quotes from Deuteronomy 24:1-4, merely stating that Moses allowed for divorce. Their selective use (printed in bold below) of the Deuteronomy text becomes clear when the latter's context is kept in mind. The NIV version reads:

If a man marries a woman who and she then becomes displeasing to him because he finds 'something indecent' about her, and he writes her a certificate of divorce, gives it to her and sends her from his house, and if after she leaves his house she becomes the wife of another man, and her second husband dislikes her and writes her a certificate of divorce, gives it to her and sends her from his house, or if he dies, then her first husband, who divorced her, is not allowed to marry her again after she has been defiled. That would be detestable in the eyes of the Lord.

The passage does not deal with divorce, or the motivation for it, in the first place (cf. Rogerson 2003:167). The focus is rather on the defilement of a divorced woman that remarries. The exclusive male perspective of the passage is conspicuous. Only the male may initiate divorce, virtually for any reason. The indecency (it is unclear to what erwat dabar precisely refers to ${ }^{9}$ ), mentioned in verse 1 , is from a male perspective.

9.In Judaism the Shammai-school took it to mean 'unchastisy' whereas the Hille Billerbeck (1926:315-318) list all the reasons which the Hillel-school stlow and Billerbeck (1926:315-318) list all the reasons which the Hillel-school allowed, for example any transgression of the law by the wife, action by her that would give the husband a bad reputation, childlessness or any breaking of the conditions on which the marriage was concluded. Jesus seems to be nearer to the Shammai-school, although his view is more radical: humans should not divorce at all. Referring to
Leviticus 18:1-20, Schweizer (1973:76) speculates that Jesus would only have
If the woman remarries, divorces again or becomes a widow she is considered as defiled and her first husband may not marry her again. From a pro-woman perspective (of which the Pharisees in all probability also suspected Jesus) such remarriage could have been regarded as an act of reconciliation, instead of being 'detestable in the eyes of the Lord' $^{10}$

Deuteronomy 24:1-4 clearly provides a challenge to the stance of the historical (or even any synoptic) Jesus. In ancient Israel, as expressed for example in this Mosaic law, there were various despised categories of women such as barren women (Lk 1:25) and prostitutes (Lk 7:36-50) for example. Jesus' association with women and prostitutes challenged these attitudes. The Markan Jesus (and probably also the historical one) criticises the Mosaic law by stating that it is because of the hardness of the human heart (mpòs

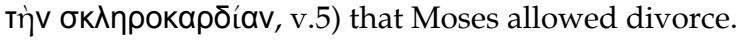

\section{Jesus' appropriation of the Torah substantiating his stance on divorce}

Jesus' motivation for being against divorce does not consist of a detailed discussion and repudiation of the biases of Deuteronomy 24:1-4, but in quoting from the creation narratives of Genesis 1 and 2.11 This time Jesus' quotation from the Torah seems to be in full approval of the latter, not only recognising but calling on its authority. Genesis 1:27 states:

So God created man in his own image, in the image of God he created him; male and female he created them.

Jesus' quotation of this verse is also selective. The first part of the verse is summarised in Mark 10:6 as 'at the beginning of creation' and only the latter part ('male and female he made them') is directly quoted. Jesus thereby avoids the exclusive male bias of Genesis 1:27a ('man, him') and emphasises that humans were created as male and female. Like the Hebrew

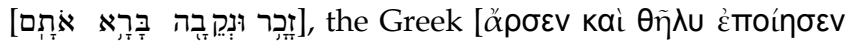
aútoú $]$ emphasises human sexuality (Westermann 1974:220 222; Kroeze 197 0:17; Scheffler 2008:1263-1265). Jesus thereby fully subscribes to the existence and sexuality of the two sexes. With him there is no 'celibate' wish that it would have been better if different sexes did not exist or that one should act as if they do not exist (cf. the disciples' remark in Mt 19:11 and Paul in 1 Cor 7:1, 7, 38, 40), in which case divorce would not have been an issue.

(Footnote 9 cont...)

allowed for divorce in case of incest, in which case the marriage should not have taken place in the first place.

10.Rogerson (2003:167) mentions the possibility that 'the old taboo' was made as a 'humanitarian attempt to prevent the first husband from getting a second payment of "bride's wealth"'. If this is true, then present-day 'pro-women' perspectives
applied to the text are anachronistic and uncalled for. On the other hand, the exclusive male perspective of the text should not too easily be camouflaged by what remains a 'possible interpretation'.

11.Jesus most probably engaged orally with the Old Testament tradition, which explains why he did not challenge the Pharisees regarding their selective reading of Deuteronomy 24:1-4. In all probability he had no detailed knowledge of Deuteronomy 24:1-4 (like even the average Bible reader today doesn't have either!). However, his mere quoting and particular use of Genesis 1 and 2 reflect a more women-friendly attitude than that of Deuteronomy 24:1-4. 
This pro-sexual attitude of the (Markan) Jesus is even more emphasised by his second quotation from Genesis 2:24:

For this reason a man will leave his father and mother and be united to his wife, and the two will become one flesh.

The fact that some manuscripts omit the phrase 'and cleave unto his wife' does not euphemise the expression 'kai esontai oi duo eis sarka mian (ehad basar)', as some translations (e.g. the Good News Bible) do. ${ }^{12}$ 'Becoming one flesh' constitutes an explicit reference to the sexual act and not only affirms sexuality, but in this context draws on the fact of sexual act as an argument that humans should not divorce. In the Markan text Jesus in fact employs the expression 'mia sarx' twice. He proceeds by interpreting sex as a divine act ('o theos sunezeuxen', 'what God joined together') which human's should not nullify ('anthropos me gorizeto'). It is as if the Markan Jesus argues: 'How can two people divorce if they had sex together?'

At home, Jesus and his disciples once again reflected on the issue of divorce. What is interesting here is that divorce is now related to the act of adultery against the partner. In the Pentateuch adultery occurred when a male would divorce in order to marry another woman. According to Jesus, this is wrong and constitutes the transgression of the 6th commandment. But for the Markan Jesus this is not a rule that applies to males only. Women who divorce in order to remarry also commit adultery. According to Crossan (1991:301-302), this is one of the texts that illustrates that Jesus had a programme that advocated equality between men and women. Schweizer (1973:73-74) also emphasises that Jesus' strict attitude concerning adultery and divorce was to the benefit of women.

\section{Compassion as Jesus criterion for criticising or appropriating the Torah}

From the discussion it becomes clear what criterion Jesus used in his thinking. In fact, he mentioned it explicitly: the human 'sklerokardian' [hardness of heart]. In his view, divorce implies that the divorcee would suffer (cf. the term 'against'). According to Tuckett (2000:906), this should be viewed as an ideal for the 'end time', which, if taken too strictly in a fallen world of today, would amount to the 'worst kind of legalism.' However, our present-day concerns (where divorcees in any case are supposed to be cared for) should not allow us to overlook Jesus' reasoning in his context. A divorced woman in his day could be compared to a widow with no security, except that she was perhaps even worse off, because we find no admonition in the law that she should be cared for like the 'widow, orphan and stranger'.

It should also be kept in mind that Jesus' teaching did not lead to an official (legal) prohibition of divorce in the contemporary Jewish-Roman society. Jesus' stance on divorce should rather

12.Bratcher and Nida's (1961:311) recommendation that verses 7 and 8 should be translated with care, because 'any explicit reference [to sexuality] is likely to be regarded as vulgar' and obscures the real meaning of the text. This is actually amazing, the more so because it is made in a book that discusses the proper translation of the gospel! be interpreted as an appeal to his followers not to divorce in a context in which divorce was a legal possibility. The Markan Jesus (and most probably the historical one, cf. 1 Cor 7:10) in all probability warned against it in his own context because of the pain it inflicts on women and children (and, according to $\mathrm{Mk}$ 10:12, even men who became divorcees).

A note on the position of children is in order here. They were the really voiceless in the contemporary society (Oepke 1954:639; Scheffler 1993:74-75) and even in the Markan text their experience of the divorce of their parents is not directly reflected upon. However, it is noteworthy that the pericope on Jesus' positive attitude towards children follows directly after the one on divorce (Mk 10:13ff). It will probably remain a question whether meaning can be derived from this juxtaposition, or whether the two pericopies are 'exchangeable' in terms of the theory of Mark's Gospel as a 'Episodische Erzählung' [episodic narrative] (Breytenbach 1984:82-84). From an analogical perspective, virtually in all cultures (especially monogamous ones) the human mind is well aware of the acute pain and disruption that divorce causes children. To my mind, it is therefore unthinkable that neither the redactor, nor any reader (first, implicit or contemporary) of the Markan gospel would not make the association between Jesus' teaching on divorce and the marginalised social position of children. According to Saldarini (2003:1043) 'the defense of marriage leads naturally to concern for children who are brought to Jesus...'

\section{Divorce, monogamy and polygamy in Jesus' context}

Considering Jesus' stance on divorce, another issue about Jesus' context (which often becomes blurred when reading the text with modern eyes) is that of monogamy and (or versus?) polygamy. I refer to Tuckett (2001:906) again, who refers to Jesus quoting of Genesis 2:24 (man becoming one flesh with his wife) as expressing 'the ideal ... [of] 'life-long monogamous marriage'.

It should be noted that Genesis 2:24 functioned in a text and ancient society where polygamy (or rather polygyny) ${ }^{13}$ was allowed (see De Vaux 1968:24-26; Dorey 2003:198-2003). There is simply no reference to exclusive monogamy in Genesis, nor is there in Mark 1:1-12. Both the ancient Israelite society, as well as the Jewish society of which Jesus was part of, allowed for polygamy (although most people, about 70\%, chose monogamy). Lohmeyer (1967:200-201) is one of the few commentators on the gospel that remarks that in Jesus' day polygamy was an option.

Keeping the possibility of polygamy in mind, the (Markan) Jesus' admonition against divorce should therefore rather be understood as addressing a situation where people are left homeless because men would marry again without taking

13.Strictly taken the term polygamy can refer to both polygyny (a husband with more than one wife) and polyandry (a wife with more than one husband). The biblical text only refers to polygyny, with the result that the term polygamy usually also refers to a husband having more than one wife. 
responsibility for the first wife. Nothing is said about a person who marries again without divorcing the existing wife. The text, furthermore, clearly communicates that for Jesus it was not merely a question of economics, but the fact that man and wife had been involved in an intimate relationship (one flesh), which he interprets as an act of God (Mk 10:9).

Referring to Mark 10:1-12 Tuckett (2001) remarks:

Jesus' saying is not necessarily a legal ruling which brooks no exception (as it has frequently been taken) ... It is an ideal for the Eschaton...To apply Jesus' sayings to this situation as a legal ruling forbidding divorce under all circumstances is probably the worst kind of legalism: in the teaching of Jesus, any ideals of the eschatological kingdom would always have to be tempered by the overriding concerns of compassion and love.

(Tuckett 2001:906)

It stands to reason that if Jesus' teaching against divorce is to be applied in a context today, where monogamy is the generally accepted standard, that it could indeed amount to the 'worst kind of legalism'. But is not the fact that in the society of the developed world monogamy is the only option not in itself the 'worst kind of legalism' (being the direct cause of numerous cases of divorce)? Helander (quoted in Du Toit 1967) challenges so-called Christian values in this regard:

What have we done in the name of Christianity? Polygamy which Christ does not forbid, we have fought against as the greatest of all evils, but divorce and remarriage, which he does forbid, we have introduced.

(Helander, quoted in Du Toit 1967:149)

To conclude: Jesus of Mark's gospel (and in all probability also the historical one) stands in a tradition where the Torah of Moses has a position of authority in society. He draws on that tradition and appropriates it fully by entering into dialogue with the tradition if he differs from it. However, as can be seen from his reference of Genesis 2:24, he uses the authority of the tradition to state his case. The idea of human compassion seems to be his criterion in deciding what to criticise and what to condone. ${ }^{14}$

\section{The Matthaean Jesus on divorce}

Considering Matthew 19:3-12, Matthew renders the whole Markan version, but does some noteworthy redaction which indicates that he attempted to be less critical towards the Torah than Mark. This can be explained in view of the Matthaean Jesus' view on the Mosaic law as expressed in Matthew 5:17-19, namely that he did not come to destroy the law ('one jot or tittle shall in no wise pass from the law'), but to fulfill it. The Matthaean Jesus seems therefore more apt to reinterpret the Torah than to criticise it. As far as divorce is concerned, he achieves this in Matthew 19:9 (repeated in Mt 5:32) by inserting the words me epi porneia (translated by the King James' Version as 'saving for the cause of fornication' and the NIV as 'marital unfaithfulness'). In the Matthaean context, porneia can function as the unknown ground suggested in Deuteronomy 24:1-4 on account of which

14.Tuckett (2001:906) also advocates the criterion of 'compassion and love' but applies it to criticise the teaching of Jesus. divorce by the male partner is allowed. It should be noted that the act of divorce constitutes adultery and not porneia (which in Matthew is a reason for an exception for nondivorce). Although in agreement with Mark that sklerokardia ['hardness of heart'] was the cause for Moses allowing divorce, through mentioning the exception of porneia the provisions provided by Mosaic law seem to be met and an open rejection of the Torah is avoided.

Furthermore, in both the Matthaean accounts the case of women divorcing men is not mentioned (as in Mk 10:12). Whereas Mark interprets the prescript regarding divorce applicable for both sexes, Matthew only refers to it as being a male option (as in Dt 24:1-4). What actually happens in Mark is that the law as it pertains to women in Deuteronomy 24 (no divorce possibility) is applied to men. The Matthaean version reflects an exclusive male perspective and is thereby also more in accordance with Mosaic law.

The additions to the Matthaean version in 19:10-12 is also of significance. It appears that the Matthaean Jesus had a stricter sexual morale than the Markan or the historical one. For Matthew's Jesus fornication is a ground for divorce and abstinence (through castration, for the sake of the kingdom) seems to be lauded (although not compulsory).

The addition in Matthew 19 can be interpreted in conjunction with Matthew 5:28, which states that looking with lust at a woman already constitutes an act of adultery with the desired women. Matthew 5:29-30 continues to suggest voluntary castration (which hardly can be taken literally) in order to avoid lust and adultery. Immediately after this 'hedge around the Torah', divorce is referred to: it is only allowed parektos logou pornaias. As would be later confirmed in the rendering of Mark's version in 19:1-9, only porneia may allow for divorce. The male perspective is significant: although it was the man that initiated the process, the divorced woman is regarded as the one committing adultery. Another difference with Mark (and in all probability the historical Jesus) is that the divorced woman may not marry again (in which case the man is the adulterer). This strict measure that leaves a divorced woman completely out in the cold is also in accordance with Deuteronomy 24:1-4.

\section{Conclusion}

\section{Jesus the (compassionate) critical Jew for today}

It appears from our investigation that the Markan (and historical) Jesus criticised the Torah if deemed necessary. However, in the process of criticising scripture, scripture itself is employed, with compassion as the criterion. Matthew's Jesus functions within the same tradition, but an attempt is made to minimise the notion of 'criticising scripture'. In Matthew's Gospel there is a debate with the Mosaic law which must be fulfilled (Mt 5:17-20). The six antitheses of the Sermon on the Mount (including the commands against adultery and divorce) should therefore not from a present-day perspective be interpreted as the abolishment of the law, but rather as a radical reinterpretation or intensification of it. The disciples 
of Matthew's gospel should in principle still listen to the Pharisees sitting in Moses' seat (Mt 23:2). It seems that, in his depiction of Jesus, Matthew struggled to overcome the cognitive dissonance which he experienced by condoning the teachings of Jesus, whilst attempting to adhere to the Torah.

Numerous other examples of Jesus' critique and appropriation of the Pentateuch (and the Old Testament) as it appears in the Gospels can be mentioned (e.g. the keeping of the Sabbath, love for the enemy). Loving God and the neighbour constitutes not only the criterion, but the essence of Jesus' interpretation of his Jewish tradition (Stauffer 1959:40-48). Noteworthy in Matthew's rendering (Mt 22:34-39), the Torah and Prophets are explicitly mentioned and sustained. The law of love depends on it.

Does Jesus' stance have relevance for Christianity (and humanity) today? If it is part of our value system that human suffering should be alleviated and that it is love that makes the world go round, one can surely conclude that the selfconfessed 'atheist' Dawkins is correct in his claim that Jesus of Nazareth provided the key on how we should apply the Pentateuch (and the Bible as a whole) to our lives.

Jesus was no critical biblical exegete in the modern sense of the word and his use of the text of the Torah reflects that he did not read the latter historically. He was not even a scribe of his day. On the contrary, he was in all probability analphabetic and the contents of the Pentateuch were in all likelihood transmitted to him orally. He never as such rejected the broader tradition from which he came, but was, rather, inspired by it. On the other hand, he was not uncritical towards that very tradition. He was not dominated or suppressed by it. He rather engaged with his tradition as a creative thinker and could even criticise it if the criterion of human love and compassion demanded it.

Jesus' stance reveals that he had the profound insight that the biblical tradition does not represent a unified view on all issues and ethical matters. In the Pentateuch he detected thoughts and values that could even contradict one another and that could be interpreted to be in debate with one another. He could therefore use pronouncements (e.g. on divorce, the enemy) in the Pentateuch to criticise and relativise other pronouncements that he regarded not to be in accordance with his own value system. In that sense Jesus of Nazareth even today challenges the way the Bible is regarded and misused as the 'authoritative Word of God' in contemporary mainstream Christianity, in the process violating the concept of love.

\section{Acknowledgement}

To Andries van Aarde, with friendly appreciation and especially for his quest for and appropriation of the historical Jesus.

\section{References}

Aland, K. (ed), 1973, Synopsis quattuor evangeliorum: Locis parallelis evangeliorum apocryphorum et partum adhibitis, Württembergische Bibelanstalt, Stuttgart.

Bornkamm, G., [1956] 1975, Jesus von Nazareth, Kohlhammer, Stuttgart.

Bratcher, R.G. \& Nida, E.A., 1961, A translater's handbook on the gospel of Mark, Brill, Leiden.

Breytenbach, C., 1984, Nachfolge und Zukunfterwartung nach Markus, Theologischer Verlag, Zürich.

Brink, A., 2009, 'n Vurk in die pad: 'n Memoir, Human \& Rousseau, Kaapstad.

Bultmann, R., 1968, Theologie des Neuen Testaments, 6. Aufl., Mohr Siebeck, Tübingen.

Crossan, J.D., 1991, The historical Jesus: The life of a Mediterranean Jewish peasant, T\&T Clarke, Edinburgh.

Crossan, J.D., 1994, The essential Jesus: Original sayings and earliest images, HarperSanFrancisco, San Francisco.

Crossan, J.D. \& Reed, J.L., 2001, Excavating Jesus: Beneath the stories, behind the texts, HarperSanFrancisco, San Francisco.

Davies, P.R., 1998, Scribes and the schools: The canonization of the Hebrew Scriptures, Westminster John Knox Press, Louisville.

Dawkins, R., 2005, 'Atheists for Jesus', Free Inquiry 25(1), 9-10.

Dawkins, R., 2006, The God delusion, Bantam Press, London.

De Vaux, R., 1968, Ancient Israel: Its life and institutions, Darton, Longman and Todd, London.

Dorey, P.J., 2003, ‘Genesis 2:24 - Locus classicus vir monogamie?: 'n Literêr-historiese ondersoek na perspektiewe op poligamie in die Ou Testament', PhD proefskrif, Departement Ou Testament, Universiteit van Pretoria.

Du Toit, H.D.A., 1967, Die kerstening van die Bantoe, N.G. Kerk-boekhandel, Pretoria.

Evans, C.A., 2003, 'Mark', in J.D.G. Dunn \& J.W. Rogerson (eds.), Eerdmans commentary on the Bible, pp. 1064-1103, Eerdmans, Grand Rapids.

Grundmann, W., 1973, Das Evangelium nach Markus, 6. Aufl., Evangelische Verlaganstalt, Berlin.

Grundmann, W., 1972, Das Evangelium nach Matthäus, 3. Aufl., Evangelische Verlaganstalt, Berlin.

Kroeze, J.H., 1970, Die Bybel en seks, Boekhandel De Jong, Johannesburg.

Lohmeyer, E., 1967, Das Evangelium des Markus, Vandenhoeck \& Ruprecht, Göttingen.

Machoveč, M., 1972, Jesus für Atheisten, Kreuz Verlag, Stuttgart.

Niditch, S., 1993, War in the Hebrew Bible, Oxford University Press, New York.

Oepke, A., 1954, s v pais ktl., ThWNT.

Rogerson, J., 2003, 'Deuternonomy', in J.D.G. Dunn \& J.W. Rogerson (eds.), Eerdmans Commentary on the Bible, pp. 153-173, Eerdmans, Grand Rapids.

Saldarini, A.J., 2003, 'Matthew', in J.D.G. Dunn \& J.W. Rogerson (eds.), Eerdmans Commentary on the Bible, pp. 1000-1063, Eerdmans, Grand Rapids.

Scheffler, E.H., 1993, Suffering in Luke's Gospel, Theologischer Verlag, Zürich.

Scheffler, E.H., 2008, 'Eros as godsdiens (of die religieuse viering van seks)', HTS Teologiese Studies/Theological Studies 64(3), 1255-1277.

Scheffler, E.H., 2009a, 'War and violence in the Old Testament world: Various views', in J.T. Fitzgerald, F.J. van Rensburg \& H.F. van Rooy (eds.), Animosity, the Bible, and us: Some, North American and South African perspectives, pp. 1-17, Society of Biblical Literature, Atlanta.

Scheffler, E.H., 2009b, 'Jesus the Jew for today: A hermeneutical exercise', Acto Patristica et Byzantina 20, 217-241.

Schnelle, U., 2007, Theologie des Neuen Testaments, Vandenhoeck \& Ruprecht, Göttingen.

Schröter, J., 2006, Jesus von Nazareth, Evangelische Verlagsanstalt, Leipzig.

Schweitzer, A., [1906] 1984, Geschichte der Leben-Jesu-Forschung, Mohr Siebeck, Tübingen.

Schweizer, E., 1973, Das Evangelium nach Matthäus, Vandenhoeck \& Ruprecht, Göttingen.

Spong, J.S., 2007, Jesus for the non-religious, HarperSanFrancisco, San Francisco.

Stauffer, E., 1959, Die Botschaft Jesu: Damals und heute, Francke Verlag, Bern.

Strack, H.L. \& Billerbeck, P., 1926, Das Evangelium nach Matthäus erläutert as Talmud und Midrasch, C.H. Beck'sche Verlagsbuchhandlung, München.

Tuckett, C.M., 2001, 'Mark', in J. Barton \& J. Muddiman (eds.), The Oxford Bible Commentary, pp. 886-922, Oxford University Press, Oxford.

Van Dyk, P., 2003, 'Violence and the Old Testament', Old Testament Essays 16, 96-112.

Vorster, J.N., 2008, 'Rhetorically reflecting on 'Jesus' research', Theologia Viatorum $32(2), 6-48$.

Westermann, C., 1974, Genesis: Kapitel 1-11, Neukirchener Verlag, Neukirchen. 